\title{
Locally Advanced Undifferentiated Pleomorphic Sarcoma
}

National Cancer Institute

\section{Source}

National Cancer Institute. Locally Advanced Undifferentiated Pleomorphic Sarcoma. NCI

Thesaurus. Code C160919.

An undifferentiated pleomorphic sarcoma that has spread from its original site of growth to nearby tissues or lymph nodes. 